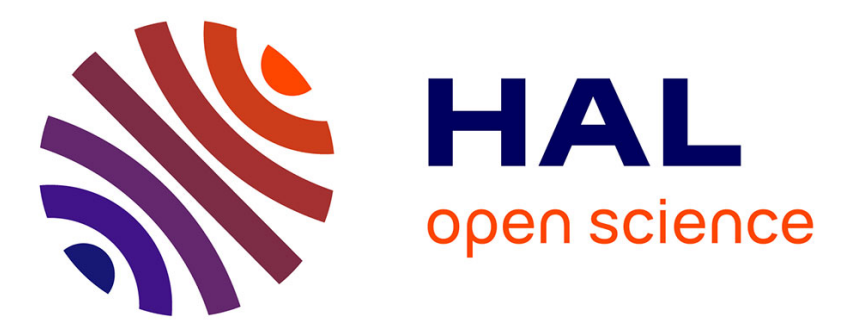

\title{
Estrogenic and anti-estrogenic activity of 23 commercial textile dyes.
}

Ingrid Bazin, Aziza Ibn Hadj Hassine, Yosra Haj Hamouda, Wissem Mnif, Ahgleb Bartegi, Miguel Lopez-Ferber, Michel de Waard, Catherine Gonzalez

\section{- To cite this version:}

Ingrid Bazin, Aziza Ibn Hadj Hassine, Yosra Haj Hamouda, Wissem Mnif, Ahgleb Bartegi, et al.. Estrogenic and anti-estrogenic activity of 23 commercial textile dyes.. Ecotoxicology and Environmental Safety, 2012, 85, pp.131-6. 10.1016/j.ecoenv.2012.08.003 . inserm-00843006

\section{HAL Id: inserm-00843006 https://www.hal.inserm.fr/inserm-00843006}

Submitted on 10 Jul 2013

HAL is a multi-disciplinary open access archive for the deposit and dissemination of scientific research documents, whether they are published or not. The documents may come from teaching and research institutions in France or abroad, or from public or private research centers.
L'archive ouverte pluridisciplinaire HAL, est destinée au dépôt et à la diffusion de documents scientifiques de niveau recherche, publiés ou non, émanant des établissements d'enseignement et de recherche français ou étrangers, des laboratoires publics ou privés. 


\title{
Estrogenic and anti-estrogenic activity of 23 commercial textile dyes
}

\author{
Ingrid Bazin ${ }^{a,}$, Aziza Ibn Hadj Hassine ${ }^{a}$, Yosra Haj Hamouda ${ }^{b}$, Wissem Mnif ${ }^{b}$, Ahgleb \\ Bartegi $^{\mathrm{c}}$, Miguel Lopez-Ferber ${ }^{\mathrm{a}}$, Michel De Waard $^{\mathrm{d}, \mathrm{e}}$, Catherine Gonzalez $^{\mathrm{a}}$ \\ ${ }^{a}$ Ecole des Mines d'Alès, LGEI center, 6 avenue de Clavière 30319 Alès Cedex, France. \\ ${ }^{\mathrm{b}}$ Laboratory of Biochemistry, Institute of Biotechnology, Monastir, Tunisia \\ ${ }^{c}$ Department of Biology, Faculty of Sciences - King Faisal University P.O. Box 175931982 \\ Al Hassa, Saudi Arabia \\ ${ }^{\mathrm{d}}$ Inserm U836, Grenoble Institut of Neurosciences, Site Santé de la Tronche, 38042 Grenoble, \\ Cedex 09, France \\ ${ }^{\mathrm{e}}$ Université Joseph Fourier, Grenoble, France \\ *Corresponding author: ingrid.bazin@mines-ales.fr
}

\begin{abstract}
The presence of dyes in wastewater effluent of textile industry is well documented. In contrast, the endocrine disrupting effects of these dyes and wastewater effluent have been poorly investigated. Herein, we studied twenty-three commercial dyes, usually used in the textile industry, and extracts of blue jean textile wastewater samples were evaluated for their agonistic and antagonistic estrogen activity. Total estrogenic and anti-estrogenic activities were measured using the Yeast Estrogen Screen bioassay (YES) that evaluates estrogen receptor binding-dependent transcriptional and translational activities. The estrogenic potencies of the dyes and wastewater samples were evaluated by dose-response curves and compared to the dose-response curve of $17 \beta$-estradiol (E2), the reference compound. The dose-dependent anti-estrogenic activities of the dyes and wastewater samples were normalized to the known antagonistic effect of 4-hydroxytamoxifen (4-OHT) on the induction of the lac $\mathrm{Z}$ reporter gene by $\mathrm{E} 2$. About half azo textile dyes have anti-estrogenic activity with the most active being Blue HFRL. Most azo dyes however have no or weak estrogenic activity. E2/dye or E2/waste water ER competitive binding assays show activity of Blue
\end{abstract}


HFRL, benzopurpurine 4B, Everzol Navy Blue FBN, direct red 89 BNL 200\% and waste water samples indicating a mechanism of action common to E2. Our results indicate that several textile dyes are potential endocrine disrupting agents. The presence of some of these dyes in textile industry wastewater may thus impact the aquatic ecosystem.

Keywords: textile dyes, estrogenic activity, anti-estrogenic activity, industrial textile effluent.

\section{Introduction}

Dyes are widely used in most industries such as those manufacturing papers, plastics, food, cosmetics, textiles or leathers. These dyes are useful to colour the final products. Dyes are classified depending on their colors, their chemical structures and/or their origin (natural or synthetic). Natural dyes most frequently originate from plants (such as riboflavin or $\beta$ carotene). Determination of the chemical structures of natural dyes and the accomplishment of their synthesis allow the gradual replacement of these natural dyes by their synthetic counterparts. Approximately 10.000 commercial dyes are used in the coloring industry. More than $10 \%$ of dyestuff used during the coloring processes does not bind to the fibers and therefore these excess dyes are released into the environment producing serious environmental pollution (Pearce et al., 2003; Rajeswari et al., 2011). The presence of these dyes in wastewater and subsequently in water resources, even at very low concentrations, is easy to observe visually as the result of textile industry activities. They may increase effluent toxicity and lead to environmental damage (Robinson et al., 2002). In addition, many synthetic dyes are poorly biodegradable. In some dyehouse effluents, dye concentration can reach up to $400 \mathrm{mg} / \mathrm{l}$ (O’Neill at al., 1999). A specific study has even demonstrated that these concentrations can exceed $600 \mathrm{mg} / \mathrm{L}$ in Nigeria (Yusuff and Sonibare, 2004). Their presence in water reduces light penetration and has a negative impact on photosynthesis. Moreover, the dyeing process itself generally also contributes to the water body contamination by chromium, zinc and copper which are all toxic to aquatic plants and fish below $1.0 \mathrm{mg} / \mathrm{L}$ (Eremektar et al., 2007; Sharma et al., 2007; Verma, 2008). The research on textile wastewater toxicity, which has been carried out so far, shows how the action of toxic dyes occurs at different levels of the food chain, from food supply (i.e. algae and plants) to consumers (i.e. crustaceans and fishes) (Manu et al., 2003; Robinson et al., 2002; Sharma et al., 2007; Soni et al., 2006; Tigini et al., 2011). Most research effort has been devoted towards elucidating or 
improving the degradation mechanisms of textile dyes with the hope to reduce their toxicity levels (Phugare et al., 2011a,b). Environmental regulations in most countries (i.e. EU directive 91/271) have prioritized in wastewater dye decontamination in order to minimize environmental damage (Robinson et al., 2001). Although the Environmental Protection Agency (EPA) has emitted new practice guidelines for environmental management, the presence of pollution dyes remains a serious environmental issue specifically for small textile industries in various countries (e.g. China, India, Taiwan) where working conditions and low economic status does not allow an efficient wastewater treatment before disposal into water sources (Mathur et al., 2005; Gregory et al., 2007; You et al., 2009). Since the mid nineties, the links between dyes, environmental impact and cancer emergence have been the subject of considerable interest both from researchers and from the general public. However, the causal relationship between dyes and certain types of cancer is difficult to establish. Several studies have been conducted on the toxicity, mutagenicity and genotoxicity of textile dyes (Bakshi et al., 2003; Ben Mansour et al., 2007; Dogan et al., 2005; Durnev et al., 1995; Mathur et al., 2007; Schneider et al., 2004). In the case of azo dyes, the increase in bladder cancer incidence, observed among textile industry workers, has been linked to prolonged exposure to these dyes. A report of experts from the "Cosmetic Ingredient Review Committee" confirmed that some anthraquinone dyes, like the disperse Blue 7 dye, used in the cosmetic industry as hair colorant and in textile, induce genotoxicity in bacteria (Cosmetic ingredient, 2007). Since then, research on these dyes confirmed their carcinogenic effects for humans and animals (Tsuda et al., 2001). This toxic effect has been linked to their presence in the environment (Dogan et al., 2005; Chou et al., 2007; Tigini et al., 2011). From an environmental point of view, toxicity, genotoxicity and mutagenicity of industrial effluents have been demonstrated (Alves de Lima et al., 2007; Grinevicius et al., 2009; Tigini et al., 2011). However, these effects have generally not been linked to the presence of dyes. Chou and collaborators associated the dioxin-like activity of some dyeing wastewater with the presence of specific anthraquinone dyes (Chou et al., 2006, 2007). In the same studies, these authors demonstrated that disperse blue 56 can bind the aryl hydrocarbon receptor (AhR), which is involved in many physiological functions such as cell regulation and reproduction. Two Brazilian studies have identified that the mutagenic activity of the Cristais River, a drinking water source of São Paulo, is caused by the presence of three blue dyes; C.I. Disperse Blue 37 contributing to $55 \%$ of this effect (De Aragão et al., 2005). 
Up to now, the estrogenic activity of dyes has seldom been studied. Rare studies mainly report the effects of food colors, such as tartazine (E102) and erythrosin B (E127). Both compounds affect chromosome structure and increase Estrogen Receptor (ER) sitespecific DNA binding to Estrogen Response Element (ERE) in HTB 133 cells (Roychoudhury et al., 1989) and in the E-screen test (Datta et al., 2008). The present manuscript investigates both the estrogenic and anti-estrogen activities of twenty three pure commercial textile dyes using the Yeast Estrogen Screen (YES). This in vitro assay has been developed for the detection of endocrine disrupting compounds (EDCs). In order to indentify estrogen and antiestrogen activity of textile dyes, the YES assay has been used to probe two different modes of action. First, a reporter gene assay measures the impact of dye binding on ER on its ability to promote binding-dependent transcriptional and translational activity. Second, an ER competitive binding assay measures how a dye competes with $17 \beta$-estradiol (E2)-dependent ER activation. In addition, the endocrine activity (estrogenic and anti-estrogenic activity) has been assessed on a textile effluent coming from a blue jean manufacturing Tunisian industry in an attempt to correlate the endocrine activity observed for commercial compounds and that obtained for dyeing wastewater.

\section{Materials and methods}

\subsection{Selected dyes}

All the dyes selected (23) in this study are used in the textile industry (Table 1 and 2). Only, 17 on 23 dyes have a known or communicated structure. The structure of the 6 other dyes were confidential and not available in the chemical abstracts service. However, the safety and chemical information certificate of analysis usually indicates the nature of the dye (azoic or anthraquinone-type chemical structure). For each dye, a stock solution (10 g/L) was prepared by dissolving in distilled water, followed by filtration through Whatmann No. 5 filter paper. All these dyes appeared perfectly soluble in water at this concentration as assessed by the absence of precipitate. For each dye, the endocrine activity was assessed at four concentrations in the range of $1 \times 10^{-5} \mathrm{~g} / \mathrm{L}$ to $1 \mathrm{~g} / \mathrm{L}$. The natural fluorescence of the dyes and their interference on the fluorescence emitted by yeast was determined beforehand in order to avoid spurious signals generated by the YES test in our experimental conditions. The fluorescence of each dye has been measured in the absence of yeast cells and subtracted from 
the data obtained for estrogenic tests. The quenching potential of the dyes was also assessed on the yeast fluorescence emission during the antiestrogenic test as follows. The fluorescence of yeast cell has been measured after $6 \mathrm{~h}$ of incubation of the reference compound E2 (from Sigma-Aldrich, St Quentin-Fallavier, France). Then, each dye was added to the medium at various concentrations and the fluorescence quenching was measured immediately. Compounds inducing more than $10 \%$ of fluorescence quenching were not investigated further for anti-estrogenic activity (noted by an asterisk in Table 2). The cytotoxicity of each dye was evaluated by measuring yeast growth at an O.D. of $600 \mathrm{~nm}$.

\subsection{Wastewater sampling and extraction}

Wastewater samples $(1 \mathrm{~L})$ were collected from the textile effluent of an industrial blue jeans factory in Tunisia. Raw water samples were centrifuged (2000 g, $15 \mathrm{~min}$ ) to eliminate solids in suspension. Supernatants were then extracted by solid-phase extraction as described by Pillon et al. (2005). Briefly, aqueous samples were concentrated on reverse-phase C18 (5 g, $20 \mathrm{~mL}$ ) cartridges (Sigma-Aldrich, St Quentin-Fallavier, France) preconditioned with methanol. Compounds elution from the column was triggered using methanol followed by hexane. Eluates were dried at $37^{\circ} \mathrm{C}$ in a rotary evaporator and residues were taken up in $2 \mathrm{~mL}$ methanol (concentration factor: 500).

\subsection{Yeast estrogen screen assay (YES)}

\subsubsection{Assay of estrogenic and anti-estrogenic activity}

Both agonist and antagonist activities of chemical dyes were examined using the Yeast strain BY4741 (Euroscarf, Frankfurt, Germany). This recombinant yeast strain carries the $\beta$ galactosidase reporter gene under the control of the ERE and contains the human ER cloned into the constitutive yeast expression vector pAAH5 (García-Reyero et al., 2001). The test measures $\beta$-galactosidase activity (fluorescence at $460 \mathrm{~nm}$ and excitation at $355 \mathrm{~nm}$ ) with a fluorimeter (Fluoroskan Twinkle LB 970, BERTHOLD Technologies) after $6 \mathrm{~h}$ of exposure to the compounds to evaluate. Tests were performed in 96-well plates. To determine the estrogen agonist activity of dyes and effluent samples, $\mathrm{E}_{2}$ was used as a positive control and distillated water was used as a negative control. Four dye concentrations were tested in the range of 
$1 \times 10^{-5} \mathrm{~g} / \mathrm{L}$ to $1 \mathrm{~g} / \mathrm{L}$. For the effluent samples, a series of dilutions (1 to 1000 of concentrated extract) were tested for their estrogenic activity. To determine the estrogen antagonist activity of the dyes, 4-OHT was used as a positive control and $\mathrm{E}_{2}(1 \mathrm{nM})$ was used as a negative control. In the antagonist test, the ability of the dye to compete with E2 for binding to ER and/or inhibit the receptor functions was evaluated. The tested dyes or 4-OHT, the positive control, were combined with $1 \mathrm{nM} \mathrm{E} 2$ before the start of the assay. All experiments were performed in triplicate. For estrogen agonist activity, the half maximal effective concentration $\left(E_{50}\right)$ was calculated based on the sigmoidal dose-effect curve of $E_{2}$. For estrogen antagonist activity, the half-maximal effective concentration $\left(\mathrm{AC}_{50}\right)$ was calculated based on the sigmoidal dose-effect curve of 4-OHT.

\subsubsection{Competitive binding assay}

Competition between dyes and/or sample effluent and E2 was measured at various concentrations of E2. Textile dye concentration used is $0.01 \mathrm{~g} / \mathrm{L}$ and the textile dyeing effluent sample at a dilution factor 5 of the concentrated extract. Thus any decrease of $\beta$-galactosidase activity after $6 \mathrm{~h}$ of exposure indicates that the dye induces a decrease in E2 binding.

\subsection{UV/Visible spectrum deconvolution}

The absorbency spectrum of a water sample can be decomposed into a few numbers of spectra (reference spectra). The shape of the UV spectrum can be considered as a linear combination of defined spectra $\left(\mathrm{REF}_{1}, . ., \mathrm{REF}_{\mathrm{p}}\right)$ related to potential compounds present in studied water sample (Thomas et al., 1996). $\mathrm{Sw}=\Sigma \mathrm{a}_{\mathrm{i}} \times \mathrm{REF}_{\mathrm{i}}+/-\mathrm{r}$, where $\mathrm{Sw}$ is the final spectra, $a_{i}$ and $r$ are the coefficient of the $i^{\text {th }}$ reference spectra and the admitted error, respectively. The Secomam company (Alès, France) has developed the UVPro software based on advanced UV spectral deconvolution (UV PRO, 2000) which allows creating dedicated models and determination of reference spectra from a set of studied wastewater UV spectra.

The UVPro software has been applied to the textile effluent of an industrial blue jeans factory of Tunisia. The reference spectra used for the deconvolution are obtained from the 23 selected textiles dyes (Table 1). Using the deconvolution model, it is possible to assess the contribution of studied dyes in the wastewater spectrum. 


\section{Results / Discussion}

3.1. Estrogenicity / anti-estrogenicity studies of individual dyes

YES allows a fast determination of both endocrine agonist and antagonist actions. The relative estrogenicity of each dye has been estimated using YES by comparison to the estrogenicity of E2 as reference compound. Typical dose-response curves for E2 have been established (data not shown). In the present study, we have essentially analyzed azo dyes. These dyes are extensively used for dyeing cotton in textile industries. By using YES assay in the present work, we have analyzed the degree of interference of textile dyes with the endocrine system considering both the potential agonist and antagonist actions. A great variability between dyes is observed. The YES assay data illustrate a dose-dependent estrogen agonist activity from $1 \times 10^{-5} \mathrm{~g} / \mathrm{L}$ to $1 \mathrm{~g} / \mathrm{L}$ for three dyes (Yellow Flavina CXL, Reactive dye red 3BS and Solvent yellow 56) (Figure 1). All these dyes have weak estrogenic effects since the maximum activity is obtained at $1 \mathrm{~g} / \mathrm{L}$. In addition, the estrogenic effect of the dyes did not saturate precluding the determination of the $\mathrm{EC}_{50}$ value, contrary to the positive control $\mathrm{E} 2$ $\left(\mathrm{EC}_{50}\right.$ value at $1 \mathrm{ng} / \mathrm{L}$ ) (Figure 1). Higher dye concentrations were not investigated, since water body dye concentration in the environment never exceeds 1 g/l. Table 2 also summarizes the fact that the twenty other dyes had no estrogenic effect by themselves. These results indicate that these dyes are not xenoestrogens that should highly impact the environment, as compared to E2 or other known xenoestrogens (e.g. bisphenol A, paraben...) (Routledge et al., 1998).

In addition, some textile dyes have an anti-estrogenic activity. The anti-estrogenic reference compound 4-OHT was used to demonstrate efficient anti-estrogenic activity when incubated in the presence of $1 \mathrm{nM} E 2$. The $\mathrm{AC}_{50}$ value of $4-\mathrm{OHT}$ was $0.5 \mu \mathrm{M}$ or $0.02 \mathrm{mg} / \mathrm{L}$ (Table 2). Similar experiments were conducted with the dyes. Only some dyes have been tested (Figure 2), the other ones, marked by an asterisks, could not been tested because they quenched the $\beta$-galactosidase fluorescence. At a concentration of $1 \mathrm{~g} / \mathrm{L}$, antagonistic activities of these dyes vary from $100 \%$ to $10 \%$ inhibition according to their colour (Table 2 and Figure 2A). Blue and red dyes show the highest inhibition potential. Everzol navy blue FBN, blue HFRL, Direct Red 89 BNL 200\% and Benzopurpurine 4B (Red 4B) are the most potent inhibitors tested. Their inhibitory effects remain however inferior to that of 4-OHT. At $1 \mathrm{~g} / \mathrm{L}$, these dyes are the only ones that induce a complete inhibition of the reporter gene in yeast 
cells. Among these four dyes, Blue HFRL is the strongest antagonist; its anti-estrogenic potency being approximately 750-fold less than that of 4-OHT. A reduction of $50 \%$ of $\beta$ galactosidase activity is observed for concentrations as low as $15 \mathrm{mg} / \mathrm{L}$. These concentration values are thus considerably lower than the total color level found in the environment (400 $\mathrm{mg} / \mathrm{L}$ ). The antagonist effect of three other dyes (Benzopurpurine 4B (Red 4B), Everzol Navy Blue FBN, and Direct Red 89 BNL) were, respectively, 3500-, 2500-, and 1250-fold less than that of 4-OHT. In contrast, all other dyes were either weak ER inhibitors or non-ER inhibitors. For instance, Everzol Blue ED, Red alpacide 3BL, Direct Blue 71, Blue ED 250, Direct Black VSF and Blue DERF were weak ER inhibitors. The anti-estrogenic activity for Blue DERF and Direct Blue 71 at $1 \mathrm{~g} / \mathrm{l}$, are $10 \%$ and 22\%, respectively. Among these dyes, most are of the azo class with sulfonated aniline (Benzopurpurine 4B, Direct Red 89 BNL $200 \%$ ) and one is an anthraquinone dye, Everzol Blue ED. The Direct Black VSF AZOFREE, Blue ED 250, both being polyazo dyes, Everzo Yellow ED and Red ED (for which no structures can be disclosed) induce inhibition of $\beta$-galactosidase expression by $\mathrm{E} 2$ with $\mathrm{AC}_{50}$ $>1 \mathrm{~g} / \mathrm{L}$.

Competition between the textile dyes and E2 was also measured by varying the concentration of E2 and maintaining a constant dye concentration $(0.01 \mathrm{~g} / \mathrm{L}$, a concentration that does not fully inhibit E2 effect, Figure 2A). Benzopurpurine 4B, Blue HFRL and Everzol Navy Blue FBN can compete with E2 for binding to ER (Figure 2B). These dyes induces a slight inhibition of E2 estrogenic activity when E2 is used at concentrations equal or lower than $1.10^{-8} \mathrm{M}$. No effect is observed for higher concentrations of E2. For example, this activity decreased from 200000 RLU without dye to 100000 RLU in presence of the Blue HFRL at $10^{-8} \mathrm{M}$ E2. This study also shows that the Red Alpacide 3BL induces a $44 \%$ inhibition of estrogenic activity and the metal-complexed azo dye yellow 4G induces a $13 \%$ inhibition (Table 2). The competitive binding assay in the YES assay showed that these dyes can bind specifically to ER in order to induce these antagonist effects.

\subsection{Estrogenicity / anti-estrogenicity studies of textile effluent}

The textile effluent sample analyzed presents a weak estrogenic effect at the maximum concentration tested (5-fold dilution). At higher concentrations of the sample, the sample compounds reduce cell viability (data not show) precluding the use of the sample for the estrogenic assay. For the dilution range (5- to 10000-fold), results from the YES bioassay 
indicate that the industrial textile effluent presents a low (below 15\%) but significant estrogenic activity (Figure 3A). Also, the effluent sample inhibits $60 \%$ of estrogenic activity (Figure 3B). In competition experiments, in which E2 concentration is varied and a single dilution dose of the effluent sample is used (5-fold dilution), the anti-estrogenic effect is observable until $10^{-5} \mathrm{M}$ of E2 (Figure 3C). The competition effect of the sample is most significant at $10^{-8} \mathrm{M}$.

The composition of the effluent sample in dyes has not been fully determined. Spectral analyses indicate that most of its components are blue dyes. Indeed, UV/Visible deconvolution of the spectrum of a blue jeans manufacturer's effluent of Tunisia indicates that the sample contains mainly Blue DERF, Direct Blue 71, Everzol navy Blue FBN, and Grey GGL dye according to the spectrum of each individual dye (Figure 4). The deconvolution of the sample spectrum did not predict the presence of other dyes. Interestingly, our studies have demonstrated that at least three of these dyes presented anti-estrogenic activity with the YES assay. Most blue and navy blue dyes are derived from the Reactive Black 5 azo dye, which is classified Xn (harmful). It is also suspected to be mutagenic and to be associated to bladder cancer development (You et al., 2009). Nevertheless, without a complete characterization of the nature of the dyes being released in the local environment of this factory, the antestrogenic effect of the effluent sample can't be unequivocally be attributed to these blue dyes. Since this effluent is essentially blue, and that some blue dyes are among those presenting the highest anti-estrogenic effect, suspicion remains however high that this Tunisian factory releases harmful components in the environment. In addition, it is worth noting that the most active dyes have anti-estrogenic $\mathrm{AC}_{50}$ values (between $15 \mathrm{mg} / \mathrm{L}$ and 70 $\mathrm{mg} / \mathrm{L}$ ) that are well below the dye concentration that can be detected in some water bodies $(400 \mathrm{mg} / \mathrm{L})$. If these same dyes are indeed present in the environment, they would present a real anti-estrogenic activity to local water consumers.

\section{Conclusions}

Our results on the endocrine effects of textile dyes come in complement of those already published on the carcinogenic and mutagenic effects of dyes. They point to the fact that some dyes, mainly blue and red dyes, may be endocrine disruptor compounds. These observations raise two issues. Concerning environmental pollution, some of these dyes may be present at concentrations high enough that they may indeed affect life quality by promoting 
tumor generation. Textile sewage is therefore a potential health hazard that should require a better communication on the dyes used by the industry and its method of disposal. In that respect, it appears as particularly important to efficiently treat industrial effluent containing azo dyes before they get discharged into the environment. The second issue concerns the pharmacological effect of these textile dyes. Besides 4-OHT, few compounds have antiestrogenic activity. It is therefore of interest to note that some of the dyes that we characterized have similar anti-estrogenic activity, suggesting that they may be lead compounds for the development of new 4-OHT like anti-estrogenic compounds.

\section{References}

Alves de Lima, R.O., Bazo A.P., Salvadori, D.M., Rech, C.M., de Palma Oliveira, D., de Aragão Umbuzeiro, G., 2007. Mutagenic and carcinogenic potential of a textile azo dye processing plant effluent that impacts a drinking water source. Mutat Res. 626 (1-2), 5360 .

Baêta, B.E., Aquino, S.F., Silva, S.Q., Rabelo, C.A., 2011. Anaerobic degradation of azo dye Drimaren blue HFRL in UASB reactor in the presence of yeast extract a source of carbon and redox mediator. Biodegradation, DOI: 10.1007/s10532-011-9499-4.

Bakshi, D.K., Sharma, P., 2003. Genotoxicity of textile dyes evaluated with Ames test and rec-assay. J Environ Pathol Toxicol Oncol. 22 (2), 101-9.

Ben Mansour, H., Corroler, D., Barillier, D., Ghedira, K., Chekir, L., Mosrati, R., 2007. Evaluation of genotoxicity and pro-oxidant effect of the azo dyes: acids yellow 17, violet 7 and orange 52, and of their degradation products by Pseudomonas putida mt-2. Food Chem Toxicol. 45 (9),1670-7.

Chou, P. H., Matsui, S., Matsuda, T., 2006. Detection and identification of dyes showing AhR-binding affinity in treated sewage effluents. Water Sci Technol. 53 (11), 35-42.

Chou, P. H., Matsui, S., Misaki, K., Matsuda, T., 2007. Isolation and identification of xenobiotic aryl hydrocarbon receptor ligands in dyeing wastewater. Environ Sci Technol. $41(2), 652-7$.

Cosmetic Ingredient Review Expert Panel., 2007. Final report on the safety assessment of disperse blue 7.Int J. Toxicol. 26, suppl 2, 65-77; DOI: 10.1080/10915810701351210 
Datta, P., Lundin-Schiller, S., 2008. Estrogenicity of the synthetic food colorants tartrazine, erythrosin $\mathrm{B}$, and sudan $\mathrm{I}$ in an estrogen-responsive human breast cancer cell line. Journal of the Tennessee Academy of Science, 83 (4).

De Aragão Umbuzeiro, G., Freeman, H. S., Warren, S. H., de Oliveira, D.P., Terao, Y., Watanabe, T., Claxton, L. D., 2005. The contribution of azo dyes to the mutagenic activity of the Cristais River. Chemosphere. 60 (1), 55-64.

Dogan, E.E., Yesilada, E., Ozata, L., Yologlu, S., 2005. Genotoxicity testing of four textile dyes in two crosses of Drosophila using wing somatic mutation and recombination test. Drug Chem Toxicol. 28 (3), 289-301.

Durnev, A. D., Oreshchenko, A. V., Kulakova, A.V., Beresten, N. F., 1995. Analysis of cytogenetic activity of food dyes. Vopr Med Khim. 41 (5), 50-3.

Eremektar, G., Selcukb, H., Mericc, S., 2007. Investigation of the relation between COD fractions and the toxicity in a textile finishing industry wastewater: effect of preozonation. Desalination 211, 314-320.

García-Reyero, N., Grau, E., Castillo, M., López de Alda, M. J., Barceló, D., Piña, B., 2001. Monitoring of endocrine disruptors in surface waters by the yeast recombinant assay. $\mathrm{J}$. Environ Toxicol Chem. 20 (6), 1152-8.

Gregory, P., 2007. Toxicology of textile dyes in "environmental aspects of textile dyeing" in Environmental aspects of textile dyeing; Christie R .M. eds.; WP chp 3, pp 44-73.

Grinevicius, V. M., Geremias, R., Laus, R., Bettega, K. F., Laranjeiras, M. C., Fávere, V. T., Wilhelm Filho, D., Pedrosa, R. C., 2009. Textile effluents induce biomarkers of acute toxicity, oxidative stress, and genotoxicity. Arch Environ Contam Toxicol. 57 (2), 30714.

Manu B., Chaudhari S., 2003. Decolorization of indigo and azo dyes in semicontinuous reactors with long hydraulic retention time. Process biochemistry. 38(8), 1213-1221.

Mathur, N., Bhatnagar, P., 2007. Mutagenicity assessment of textile dyes from Sanganer (Rajasthan). J Environ Biol. 28 (1), 123-6.

Matur, N., Bhatnagar, P., Bakre, P., 2005. Assessing mutagenicity of textiles dyes from Pali (Rajasthan) using Ames bioassay applied ecology and environmental research 4(1): 111118.

O’Neill, C., Freda, R., Hawkes, D. L., Hawkes, N. D., Lourenço, H. M., Pinheiro, W. D., 1999. Colour in textile effluents - sources, measurement, discharge consents and simulation: a review. Journal of Chem Tech and Biotech. 74, (11), 1009-1018. 
Pearce, C.I., Lloyd, J.R., Guthrie, J.T., 2003. The removal of colour from textile wastewater using whole bacterial cells: a review. Dyes and Pigments. (58),3, Pages 179-196

Phugare, S. S., Kalyani, D. C., Patil, A. V., Jadhav, J. P., 2011. Textile dye degradation by bacterial consortium and subsequent toxicological analysis of dye and dye metabolites using cytotoxicity, genotoxicity and oxidative stress studies. J Hazard Mater. 186 (1), 713-23.

Phugare, S. S.,, Kalyani, D. C., Surwase, S. N., Jadhav, J. P., 2011. Ecofriendly degradation, decolorization and detoxification of textile effluent by a developed bacterial consortium. Ecotoxicol Environ Saf. 74, (5), 1288-96.

Pillon, A., Servant, N., Vignon, F., Balaguer, P., Nicolas, J. C., 2005.,In vivo bioluminescence imaging to evaluate estrogenic activities of endocrine disrupters. Anal Biochem. 340(2), 295-302.

Rajeswari, K., Subashkumar R., Vijayaraman K., 2011. Biodegradation of Mixed Textile Dyes by Bacterial Strains Isolated from Dyewaste Effluent. Research Journal of Environmental Toxicology, 5: 97-107.

Robinson, T., Chandran, B., Nigam, P., 2001. Studies on the decolourisation of an artificial textile-effluent by white-rot fungi in N-rich and N-limited media. Appl Microbiol Biotechnol. 57(5-6):810-3.

Robinson, T., Chandran, B., Nigam, P., 2002. Removal of dyes from a synthetic textile dye effluent by biosorption on apple pomace and wheat straw. Water Res. 36(11):2824-30.

Routledge, E.J., Parker, J., Odum, J., Ashby, J., Sumpter, J.P., (1998). Some alkyl hydroxy benzoate preservatives (parabens) are estrogenic. Toxical. Appl. Pharmacol. 153, 12-19.

Roychoudhury, A., Giri, A. K., 1989. Effects of certain food dyes on chromosomes of Allium cepa. Mutat Res. 223 (3), 313-9.

Schneider, K., Hafner, C., Jäger, I., 2004. Mutagenicity of textile dye products. J Appl Toxicol. 24 (2), 83-91.

Sharma, K.P., Sharma, S., Sharma, S., Singh, P.K., Kumar, S., Grover, R., Sharma, P.K.,. 2007. A comparative study on characterization of textile wastewaters (untreated and treated) toxicity by chemical and biological tests. Chemosphere. 69, 48-54.

Soni, P., Sharma, S., Sharma, S., Kumar, S., Sharma, K.P., 2006. A comparative study on the toxic effects of textile dye wastewaters (untreated and treated) on mortality and RBC of a freshwater fish Gambusia affinis (Baird and Gerard). J Environ Biol. 27(4):623-8. 
Tigini, V., Giansanti, P., Mangiavillano, A., Pannocchia, A., Varese, G. C., 2011. Evaluation of toxicity, genotoxicity and environmental risk of simulated textile and tannery wastewaters with a battery of biotests. Ecotoxicol Environ Saf. 74 (4), 866-73.

Thomas, O., Theraulaz, F., Agnel, C., Suryani, S., 1996. Advanced UV examination of wastewater. Environmental Technology, 17 (5), 251-261.

Tsuda, S., Murakami, M., Matsusaka, N., Kano, K., Taniguchi, K., Sasaki, Y. F., 2001, DNA damage induced by red food dyes orally administered to pregnant and male mice. Toxicol Sci. 61 (1), 92-9.

UVPro, 2000. Procédés et dispositifs pour la manipulation, l'archivage, la caractérisation, l'analyse d'un échantillon liquide. Patent 00402038-4

Verma,Y., 2008. Acute toxicity assessment of textile dyes and textile and dyes industrial effluents using Daphnia magna bioassay. Toxicol.Ind.Health 24,491-500.

You, S.J, Teng, J.Y., 2009. Performance and dye-degrading bacteria isolation of a hybrid membrane process. J Hazard Mater. 172(1):172-9.

Yusuff, R.O., Sonibare, J.A., 2004. Characterization of textile industries effluents in Kaduna Nigeria and pollution implications, Global Nest: the Int. J. (6),3, 212-221. 
410 Figure 1: Induction of estrogenic activities of some textile dyes. Average \pm standard 411 deviation $(n=3)$.

412

413 Figure 2: Anti-estrogenic activity of textile (A) dyes as measured by the yeast estrogen screen 414 (B). Competitive binding essay of 3 textile dyes $(0.01 \mathrm{~g} / \mathrm{l})$ against various concentrations of 415 E2. Average \pm standard deviation $(n=3)$.

416

417 Figure 3: Estrogenic (A) and anti-estrogenic (B) activity of textile effluent, (C) competitive 418 binding assay of textile effluent (dilution factor 5-fold) against various concentrations of E2. 419 Average \pm standard deviation $(n=3)$.

420

421 Figure 4: UV/Visible deconvolution of textile effluent spectrum. 
426 Table 1: Textile dyes analysed in this study. ${ }^{\mathrm{a}}$ Dyes and informations obtained by Everlight

\begin{tabular}{|c|c|c|c|}
\hline Compound & CAS \# & Family & Formula \\
\hline Benzopurpurine 4B (Red 4 B) & $992-59-6$ & azo & $\mathrm{C}_{34} \mathrm{H}_{26} \mathrm{~N}_{6} \mathrm{Na}_{2} \mathrm{O}_{6} \mathrm{~S}_{2}$ \\
\hline $\begin{array}{l}\text { Direct Black VSF AZO-FREE } \\
\text { (Direct Black 22) }\end{array}$ & $6473-13-8$ & azo & $\mathrm{C}_{44} \mathrm{H}_{32} \mathrm{~N}_{13} \mathrm{Na}_{3} \mathrm{O}_{11} \mathrm{~S}_{3}$ \\
\hline Yellow 4 G (Solvent yellow 19) & $10343-55-2$ & azo & $\mathrm{C}_{16} \mathrm{H}_{11} \mathrm{CrN}_{4} \mathrm{O}_{8} \mathrm{~S}$ \\
\hline Direct Blue 71 (Blue BRR) & $4399-55-7$ & azo & $\mathrm{C}_{40} \mathrm{H}_{23} \mathrm{~N}_{7} \mathrm{Na}_{4} \mathrm{O}_{13} \mathrm{~S}_{4}$ \\
\hline Brown RL & $12238-94-7$ & azo & $\mathrm{C}_{15} \mathrm{H}_{14} \mathrm{O}_{5}$ \\
\hline $\begin{array}{l}\text { red Alpacide 3BL } \\
\text { brown GV }\end{array}$ & $12238-49-2$ & azo & $\begin{array}{c}\mathrm{C}_{18} \mathrm{H}_{10} \mathrm{~N}_{2} \mathrm{O}_{2} \mathrm{Cl}_{2} \\
\mathrm{C}_{31} \mathrm{H}_{21} \mathrm{~N}_{7} \mathrm{O}_{6} \mathrm{Na}_{2} \mathrm{~S}\end{array}$ \\
\hline Orange 7GL & $12222-37-6$ & azo & $\mathrm{C}_{42} \mathrm{H}_{28} \mathrm{~N}_{7} \mathrm{Na}_{4} \mathrm{O}_{15} \mathrm{~S}_{4}$ \\
\hline Direct Black PMSF & & azo & $\mathrm{C}_{37} \mathrm{H}_{25} \mathrm{~N}_{5} \mathrm{Na}_{2} \mathrm{O}_{6} \mathrm{~S}_{2}$ \\
\hline $\begin{array}{c}\text { Everzol Navy Blue FBN }{ }^{\mathrm{a}} \\
\text { Blue HFRL }^{\mathrm{b}}\end{array}$ & 93912-64-2 & azo & $\mathrm{C}_{37} \mathrm{H}_{29} \mathrm{ClN}_{10} \mathrm{O}_{22} \mathrm{~S}_{7} \mathrm{Na}_{6}$ \\
\hline $\begin{array}{l}\text { Direct Red } 89 \text { BNL 200\% } \\
\text { Blue DERF }\end{array}$ & & azo & \\
\hline Everzol Yellow ED ${ }^{\mathrm{a}}$ & Confidential data & & \\
\hline Reactive dyes red 3BS (Red 195) & 93050-79-4 & azo & $\mathrm{C}_{31} \mathrm{H}_{19} \mathrm{ClN}_{7} \mathrm{O}_{19} \mathrm{~S}_{6}$ \\
\hline $\begin{array}{c}\text { Everzol Blue ED }{ }^{\mathrm{a}} \\
\text { Yellow Flavina CXL }\end{array}$ & $2580-78-1$ & antraquinone & $\mathrm{C}_{22} \mathrm{H}_{18} \mathrm{~N}_{2} \mathrm{O}_{11} \mathrm{~S}_{3} \mathrm{Na}_{2}$ \\
\hline Everzol Navy ED & $17095-24-8$ & azo & $\mathrm{C}_{26} \mathrm{H}_{25} \mathrm{~N}_{5} \mathrm{O}_{19} \mathrm{~S}_{6} \mathrm{Na}_{4}$ \\
\hline $\begin{array}{l}\text { Solvent yellow } 56 \\
\text { Yellow } 3 \mathrm{GF}^{\mathrm{b}}\end{array}$ & 2481-94-9 & azo & $\begin{array}{c}\mathrm{C}_{16} \mathrm{H}_{19} \mathrm{~N}_{3} \\
\mathrm{C}_{30} \mathrm{H}_{26} \mathrm{~N}_{4} \mathrm{Na}_{2} \mathrm{O}_{8} \mathrm{~S}_{2}\end{array}$ \\
\hline $\begin{array}{l}\text { Everzol Red ED }{ }^{\mathrm{a}} \\
\text { Grey GGL }\end{array}$ & Confidential data & & \\
\hline Blue ED 250 & $89157-03-9$ & azo & $\mathrm{C}_{31} \mathrm{H}_{24} \mathrm{ClN}_{7} \mathrm{O}_{19} \mathrm{~S}_{6} \mathrm{Na}_{5}$ \\
\hline
\end{tabular}

${ }^{a}$ Dyes and informations obtained by Everlight Chemical SA. ${ }^{b}$ Reactive azo dye (copper complex, $70 \%$ pure for Blue HFRL) kindly provided by a textile industry unfortunately there is no available information on its structure (Baêta et al. 2011)

Table 2: Relative estrogen agonistic and antagonistic activities of industrial dyes. Estrogenic activity of textile dyes $(1 \mathrm{~g} / \mathrm{l})$. The anti-estrogenic activity of textile dyes has been determinate at $1 \mathrm{~g} / 1$ and expressed in $4-\mathrm{OHT} \%$. The half maximal effective concentration (AC50) was calculated based on the sigmoidal dose-effect curve of 4-OHT.

\begin{tabular}{cccc}
\hline Compounds & $\begin{array}{c}\text { Test Estrogen } \\
\text { Screen agonist } \\
\text { activity }(\text { E2\% })\end{array}$ & $\begin{array}{c}\text { Test Estrogen Screen } \\
\text { antagonist activity }(4- \\
\text { OHT \% })\end{array}$ & $\begin{array}{c}\text { Test Estrogen Screen } \\
\text { antagonist AC 50 }(\mathrm{g} / \mathrm{l})\end{array}$ \\
\hline $\mathrm{E}_{2}\left(10^{\mathrm{E}-9} \mathrm{M}\right)$ & 100 & - & - \\
$\mathrm{OTH}$ & - & 100 & $2 * 10-5$
\end{tabular}


Benzopurpurine 4B (Red 4 B)

Direct Black VSF AZO-FREE

(Direct Black 22)

Yellow 4 G (Solvent yellow 19)

Direct Blue 71 (Blue BRR)

*Brown RL

Red Alpacide 3BL

*Brown GV

*Orange 7GL

*Direct Black PMSF

Everzol Navy Blue FBN

Blue HFRL

Direct Red 89 BNL 200\%

Blue DERF

*Everzol Yellow ED

Reactive dyes red 3BS (Red 195)

Everzol Blue ED

Yellow Flavina CXL)

Everzol Navy ED

Solvent yellow 56

Yellow 3GF

Everzol Red ED

*Grey GGL

Blue ED 250
0

100

0.07

20

$>1$

0

13

$>1$

0

22

$>1$

0

0

44

$>1$

0

0

0

0

94

0.05

0

100

0.015

0

100

0.025

0

10

$>1$

0

22

0

0

0

35

$>1$

36

0

0

0

32

$>1$

11

0

0

0

0

0

0

30

$>1$

0

0

0

0 


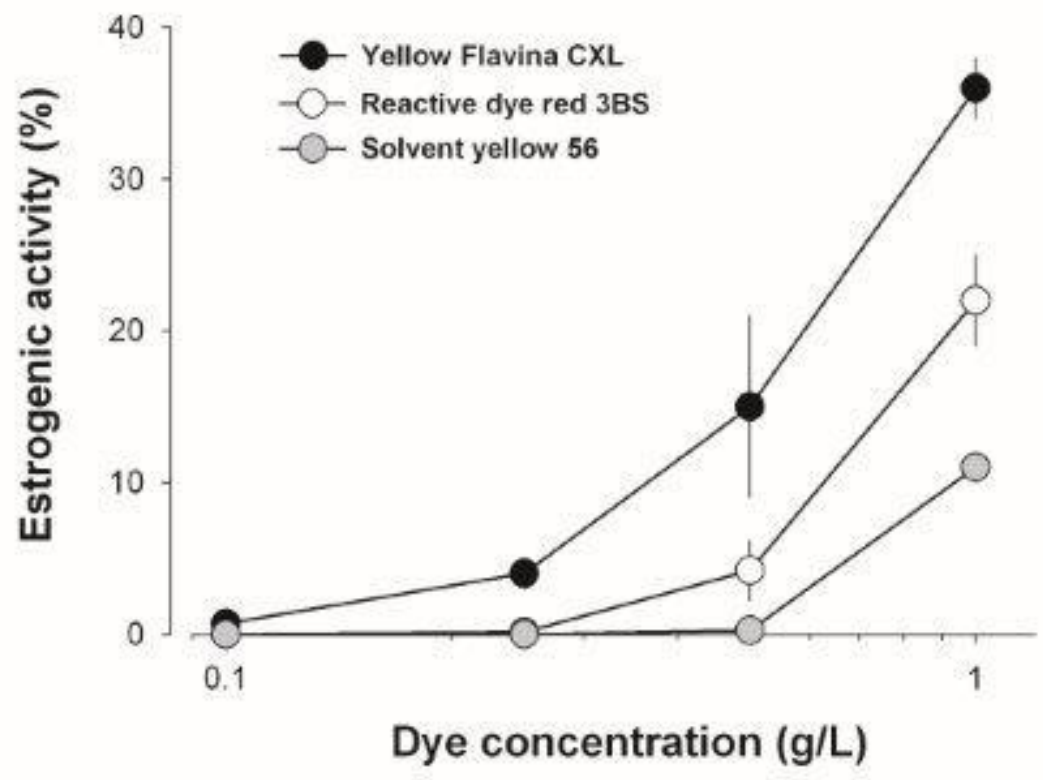


A

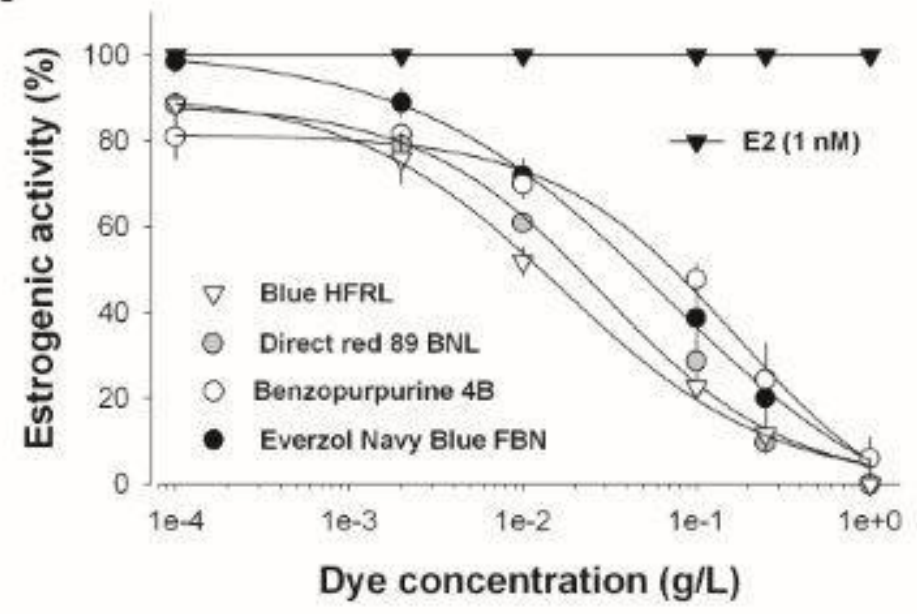

B

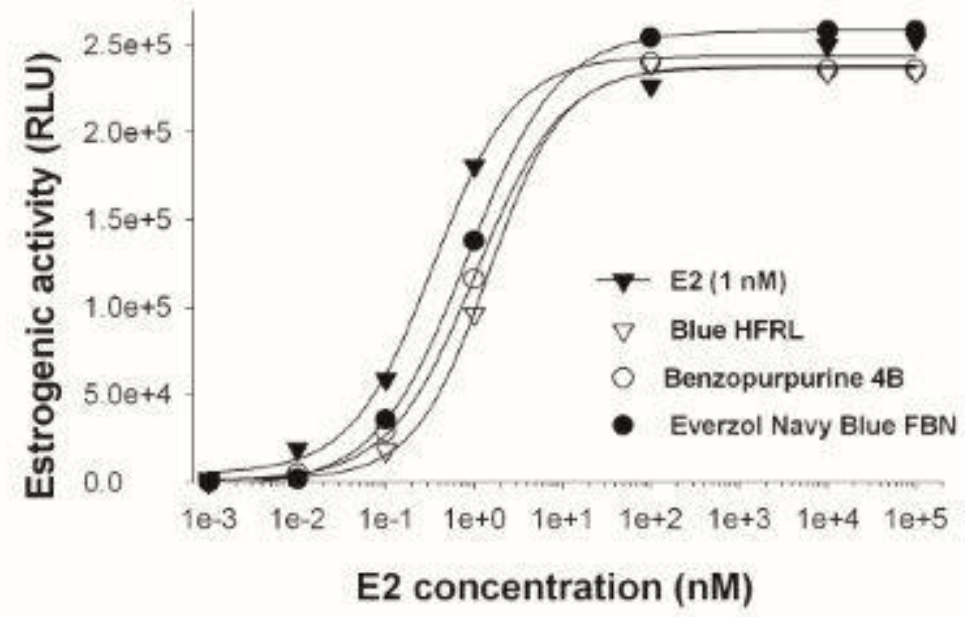




\section{A}

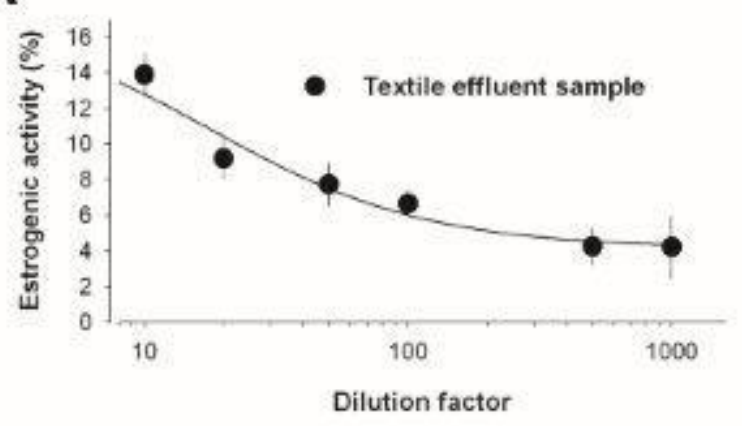

B

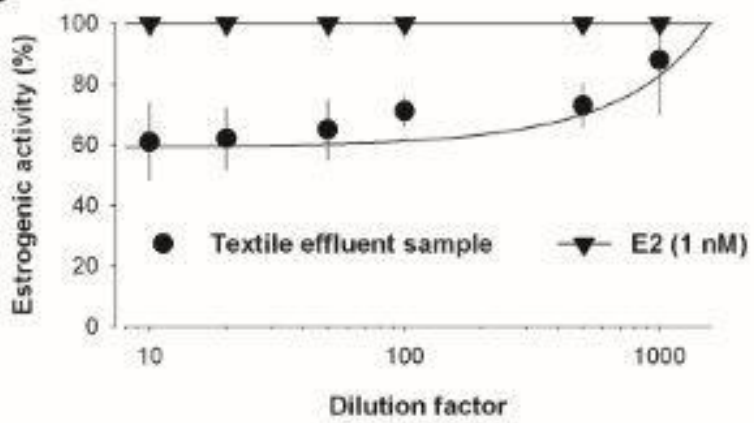

C

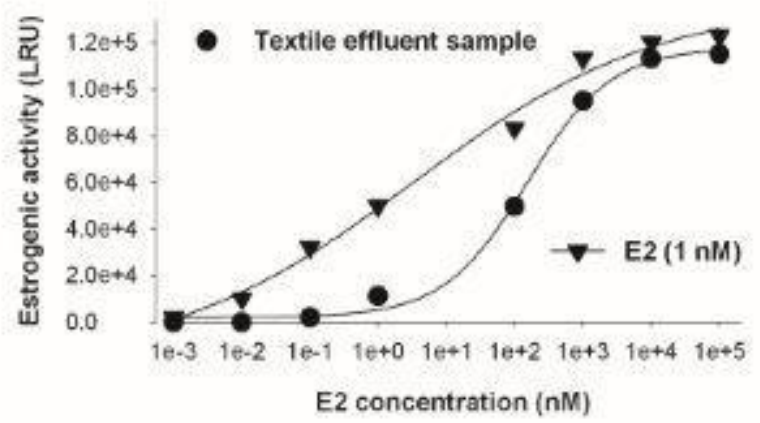

